\section{Intersections}

Canadian Journal of Music

Revue canadienne de musique
Intersections CANADIAN JOURAL OP MUSIC
REVUECANADIENER DE MUSIQUE

\title{
A Tribe Called Red's Halluci Nation: Sonifying Embodied Global Allegiances, Decolonization, And Indigenous Activism
}

\section{Alexa Woloshyn}

Volume 36, numéro 2, 2016

URI : https://id.erudit.org/iderudit/1051602ar

DOI : https://doi.org/10.7202/1051602ar

Aller au sommaire du numéro

\section{Éditeur(s)}

Canadian University Music Society / Société de musique des universités canadiennes

ISSN

1911-0146 (imprimé)

1918-512X (numérique)

Découvrir la revue

Citer cet article

Woloshyn, A. (2016). A Tribe Called Red's Halluci Nation: Sonifying Embodied Global Allegiances, Decolonization, And Indigenous Activism. Intersections, 36(2), 101-109. https://doi.org/10.7202/1051602ar
Résumé de l'article

« Nous sommes la tribu invisible. Nous vivons sur une réserve industrielle. Nous sommes la nation Halluci ». Ces paroles de l'activiste des droits autochtones et poète John Trudell (1946-2015) a inspiré le plus récent album du collectif autochtone de disc-jockeys A Tribe Called Red (ATCR), de même que sa cause pan-autochtone et transculturelle. Les relations intertribales sont à la fois fréquentes et importantes pour les communautés autochtones, particulièrement dans les centres urbains. Leurs relations intertribales sont d'ailleurs soulignées par des événements tels que des powwows, même lorsqu'ils sont organisés par une nation en particulier. Avec Halluci Nation, ATCR cherche à rassembler des allégeances communes à travers une variété de cultures, d'identités ethniques et de lieux afin de comprendre l'oppression et comment elle peut être démantelée collectivement (DJ NDN de ATCR). Cet article avance que Halluci Nation de ATCR traduit par le son une démarche de décolonisation donnant lieu à un réseau global d'alliances. Nous retraçons le développement de la musique de ATCR, à partir de son intérêt de départ pour la communauté autochtone de la région d'Ottawa et ses alliés non-autochtones, vers un appel à des relations nation-à-nation (voir le Prix Juno - album gagnant Nation II Nation, 2013), pour aboutir au récent album-concept qui cherche à rassembler ses membres à l'échelle mondiale en une réelle Nation Halluci. Les analyses de la musique de ATCR, de son public, et de l'album Halluci Nation sont effectuée dans le cadre d'une étude de la formation de communauté et de politiques identitaires dans l'action intertribale, telle que l'organisation de powwows, de centre d'amitié, et l'activisme pan-autochtone comme Idle No More.
Copyright ( C Canadian University Music Society / Société de musique des universités canadiennes, 2018
Ce document est protégé par la loi sur le droit d'auteur. L’utilisation des services d’Érudit (y compris la reproduction) est assujettie à sa politique d'utilisation que vous pouvez consulter en ligne.

https://apropos.erudit.org/fr/usagers/politique-dutilisation/ 


\title{
A TRIBE CALLED RED'S HALLUCI NATION: SONIFYING EMBODIED GLOBAL ALLEGIANCES, DECOLONIZATION, AND INDIGENOUS ACTIVISM
}

\author{
Alexa Woloshyn
}

We are the tribe that they cannot see. We live on an industrial reservation. We are the Halluci Nation ... Our DNA is of the earth and sky. Our DNA is of past and future. We are the Halluci Nation. We are the evolution, the continuation.

These words from Santee Dakota activist and poet John Trudell (1946-2015) inspired the latest album by Ottawa-based Indigenous DJ-producer collective A Tribe Called Red (ATCR) and frame its pan-Indigenous, transcultural message. Trudell was a leader in a long history of pan-Indigenous solidarity and resistance through, mostly notably, the Indians of All Tribes, which occupied Alcatraz for fourteen months in 1969-71, and the American Indian Movement. ${ }^{1}$

This article argues that ATCR's album We Are the Halluci Nation sonifies a decolonization that establishes an embodied network of global allies. I trace the development of ATCR's music from its original focus on the Ottawa Indigenous community and its non-Indigenous allies to a call for nation-to-nation relationships with the Juno Award-winning album Nation II Nation (2013), to a concept album that seeks to manifest a real "Halluci Nation" with members from around the world.

ATCR is an Ottawa-based Indigenous DJ collective, with members DJ NDN (Ian Campeau ${ }^{2}$-Anishnabe from Nipissing First Nation), 2oolman (Tim Hill-Mohawk, of the Six Nations of the Grand River), and Bear Witness (Thomas Ehren Ramon-Cayuga Six Nations). The group is most known for developing "powwow step," a genre that blends samples of powwow drumming and singing with dubstep, though they incorporate many other styles. The central role of the drum in powwow music is a natural parallel to the primacy of the beat in electronic dance music. A Tribe Called Red's Electric Pow Wow creates a "decolonizing space" (Simpson 2011, 97) for both the musicians

1 The "Red Power" movement (name coined by Vine Deloria, Jr., author of Custer Died for Your Sins) was a social movement for Indigenous self-determination in the United States. The Red Power movement includes the American Indian Movement. For more information, see Josephy (1999).

2 DJ NDN (Ian Campeau) announced on October 18, 2017 that he was leaving A Tribe Called Red. 
and listeners, an embodied sonification that has implications for urban Indigenous populations.

While powwows are a celebratory inter-tribal gathering with music, dance, vendors, and yummy food, the drum circle is the centre (Browner 2009; Scales 2012). The sound of the steady beating drum supporting the high, tense, male, Northern-style singing is now an easily recognizable sound of powwow. Powwow music is a kind of storytelling. According to Michi Saagiig Nishnaabeg writer Leanne Simpson, "Storytelling is at its core decolonizing" (Simpson 2011, 33). Indeed, it is "the physical act of gathering [that] reinforces the web of relationships that stitch our communities together." To tell stories is to present Indigenous culture and knowledge "with the goal of lifting the burden of colonialism by visioning new realities" (34).

The idea of new realities in particular can be difficult for the white settler to accept: we have a troubling fiction-the "imaginary Indian"-the result of the white settler fantasy (Francis 1992). The romanticized paintings of the noble savage in the untamed frontier betray this fantasy. And it persists in today's media with images of "Indians" in their "costumes" or non-Indigenous individuals "dressing up" for Halloween or Burning Man. We should bring a critical eye to our own sesquicentennial celebrations, which juxtapose innovation in science and technology with the "Indian Village." Erica Violet Lee (Cree) and Hayden King (Pottawatomi and Ojibwe) decried "the wigwam conspiracy," asking, "Why don't Indigenous peoples get the benefit of a contemporary existence and why are the default images in Canada 150 the performance of stereotypes?" (Lee and King 2017).

In The Inconvenient Indian, Thomas King identifies the powwow as a space in which Live Indians and Dead Indians "come together." He insists, "Live Indians dance at powwows. And when we dance, when we sing at the drum, when we perform ceremonies, we are not doing it for North America's entertainment. Where North America sees Dead Indians come to life, we see our families and our relations. We do these things to remind ourselves who we are, to remind ourselves where we come from, and to remind ourselves of our relationship with the earth. Mostly, though, we do things because we enjoy them. And because they are important" $(2012,66)$.

Thus the powwow gathering is an authentic site for modern (or "Live") Indigenous peoples, because it is an act of agency now that emphasizes community and a visioning according to Indigenous knowledge and practice. But practising Indigenous tradition does not mean denying "progress" for Indigenous communities. To invite non-Indigenous observation and participation can lead to misunderstanding at best and misrepresentation and appropriation at worst. Thus, I find it best to remember that the powwow is not for me, though I am welcome. It is for the Indigenous participants who carve out a space in a settler colonialist place to celebrate and express culture, build community, and freely embody Indigeneity. This is particularly important for urban-based Indigenous communities.

In Indigenous in the City, Chris Andersen argues that the "urban Aboriginal" has an identity distinct from northern, rural, or reserve Indigenous 
communities, based on geographic, economic, social, and political elements (2013). These "highly intra-multicultural" urban-based Indigenous communities face challenges in community formation, but these relationships are essential to thriving in urban contexts (54). Communities continuously negotiate the tensions between cultural specificity and pan-Indigeneity, often mediated through institutions like Friendship Centres. Cultural events like powwows are important for community building and fostering pride for urban Indigenous communities. Jay $\mathrm{T}$. Johnson explains that a powwow creates a temporary bounded Indigenous place: the creation of an Indigenous space of solidarity allows Indigenous peoples to experience a reprieve from an otherwise alienating urban setting (2013).

The members of ATCR explain that their early motivation was to provide a dance club night designated as an Indigenous space, for both artists and attendees alike, similar to a powwow. They began hosting a monthly club night at Ottawa's Babylon club, a night they called "Electric Pow Wow." It has been argued elsewhere that A Tribe Called Red's music and the Electric Pow Wow night extend many aspects of the traditional powwow to the club setting (Woloshyn 2015). Electric Pow Wow night became an important place for celebrating cultural self-determination while existing within a nation that has sought and still seeks to erase Indigenous cultures and communities. Babylon is not a devoted Indigenous space, but on Electric Pow Wow night the physical space becomes a hub for Indigenous solidarity (Leal 2012, 62) and cultural self-determination through the kind of community-based re-visioning that Simpson describes. This is a re-visioning that centres an urban-based Indigenous community.

ATCR's first album represents this history of the group as local party DJs, with diverse dances styles included in the tracks, such as moombahton and the now famous powwow step. This album represents their commitment to their local Ottawa Indigenous community. The most popular track on this album is "Red Skin Girl," a powwow step remix of the round dance "Red Skin Gal" by the award-winning Northern Cree Singers. The original powwow track uses both vocables and English lyrics, though ATCR samples only the English lyrics. The use of vocables, in particular, are common in powwow songs, as they facilitate intertribal connections. In "Red Skin Girl," ATCR maintains the integrity of the vocal melody and the lyrics but resituates it within $4 / 4$ metre to reinforce a dance groove and blend dubstep form with powwow song form (Woloshyn 2015, 11-12).

ATCR's sound was galvanizing for Indigenous youth, first in Ottawa, then radiating across the country. The second album entitled Nation II Nation demonstrates the group's recognition of their platform to draw attention to Indigenous artists and to build solidarity for political ends. For the former, ATCR coordinated with Tribal Spirit Music to sample contemporary powwow drum groups, many of whom sing in their first language, such as "Sisters," which samples "C Kisakitin Mama" from the women of Northern Voice. Here ATCR does not sample complete vocal phrases, and the timbral modifications to the voice sample hide the linguistic content, even for someone who might understand the Atikamekw language (Woloshyn 2015, 13-1). The remarkable 
presence of female voices only, when often women's voices are heard as supportive background in powwow songs, is further emphasized through the video by Jon Riera, which depicts three Indigenous women getting ready for and then attending Electric Pow Wow night. ${ }^{3}$

For the latter, I refer in part to DJ NDN speaking out against racist sports team names, but also to ATCR's musical support of Idle No More with the release of "The Road." ATCR's music was frequently played at Idle No More protests, as it inspired a kinaesthetic response and signified a vibrant and contemporary Indigenous voice (Perea 2013). 4

Pan-Indigenous solidarity has proven essential for Indigenous artists, activists, and scholars alike as the oppressive power of settler colonialism continues to manifest violent and far-reaching consequences. However, it can lead to the perception of a homogenous Indigenous culture with one history, one experience, and one perspective. This balance between nation-specific perspectives and pan-Indigeneity was central in Idle No More. 5 This movement emphasized the need for Indigenous sovereignty and self-determination in Canada and drew attention to common stories of oppression and forced silence, but it also made room for education about nation-specific concerns as the events spread out across the country (Kino-nda-niimi Collective 2014, 23).

As ATCR's musical reach expanded to a global scale, their conception of solidarity similarly expanded. This is in part because of what they witnessed first-hand on tour in Indigenous communities around the world who had similar stories of oppression and genocide under settler colonialism. DJ NDN reported,

I realized that colonization has a checklist. We've all been through the same thing. The Sami people and Australia's indigenous both have gone through Christian-run, government-sanctioned schooling. That's a common practice in colonization to re-program indigenous populations to take on Christianity and the value of money and disconnect from their culture and plug them into a different one. In Canada, it's been called cultural genocide. (Barnes 2016)

I will illustrate this shift from a North American Indigenous context to a global context with the transformation of "Stadium Powwow," an EP released in 2016 that features Black Bear Singers from Manawan, Quebec. The song has a slower beat than many of their upbeat tunes, and it is not until after twenty-eight seconds of introduction that the recognizable Northern style of powwow singing places this as an ATCR song. But the video, directed by Kevan Funk, immediately provides an Indigenous context with brief shots of a man in powwow regalia. Images are predominately urban: a man walking

\footnotetext{
3 For a detailed analysis and reflection on "Sisters," see Recollet (2015).

4 In addition, "The Road" is the only music for the University of Alberta Native Studies Department's new online course "Indigenous Canada" as interstitia in the video lessons.

5 I use past tense here to refer most specifically to the intensity of Idle No More events in late 2012 and 2013.
} 
and skateboarding through a city, a young boy with his skateboard, a woman boxing, in addition to shots of ATCR in concert with a hoop dancer.

The video captures diverse experiences of Indigenous communities in North America today, urban and rural contexts. A young man and woman sitting in a truck bed drive past a construction site, which calls to mind the extensive (and contentious) resource extraction on Indigenous lands across North America. Soon this young man dons his grass dance regalia, and the landscape is claimed as Indigenous space. A child catching grasshoppers is contrasted with a male adult placing a roadblock on a bridge where the sign says, "No access to UniSt'ot'en land without consent." This is the camp of the Unist'ot'en Clan on the unceded territory of the Wet'suwet'en First Nation, and they have prevented any pipeline crews from entering the area.

The man on the skateboard, the young woman in the boxing ring, the DJs in the club, and a community protest against pipelines are connected in the larger context of Indigenous identity, resilience, and resurgence within settler colonialism. "Stadium Pow Wow" is very much a song about North American Indigenous existence, as communicated through the video, which now has over two million views on YouTube.

This same track then became the first single on We Are the Halluci Nation, now entitled "R.E.D.," featuring rapper Yassin Bey, formerly known as Mos Def, and Iraqi-Canadian rapper Narcy (Yassin Alsalman). ATCR's latest album We Are the Halluci Nation is a re-visioning of nationhood and solidarity that rejects the boundaries and limits of settler colonialism, namely, the nation state. The concept of "Halluci Nation" comes from John Trudell's poem in which he contrasts the Halluci Nation with the Alie Nation. The musical collaborations reach beyond previous First Nations' allegiances to include Inuk avant-garde vocalist Tanya Tagaq, rappers of colour Yasiin Bey, Saul Williams, and Shad, and Columbian artist Lido Pimienta. This is the first album to rely heavily on new created lyrics, alongside the samples of recognizable Indigenous powwow sounds we expect in their music. They worked in person with Black Bear to create new material for this album, as opposed to only remixing powwow recordings.

The original "Stadium Pow Wow" contains only vocables in Black Bear's singing. Their part opens with a higher descending melody sung in unison, with all other components of the remix muted to expose the powerful voices. The vocal contour suggests a section akin to the lead and seconds of a traditional powwow song, but there are no solo leads. Most of Black Bear's singing is a repeated unison refrain consisting of four almost identical phrases. This overall vocal part is heard two and a half times in the song, meaning the final iteration does not include the "seconds" and tags the vocal phrase two times.

The transformation of "Stadium Pow Wow" to "R.E.D." requires space for the additional voices, namely John Trudell both in the opening and middle of the song, and raps from Bey and Narcy. "R.E.D." opens first with Trudell's words before dropping the catchy, crunchy beat from "Stadium Pow Wow." It expands the introduction of the original song to give time for Yasiin Bey's rap. Black Bear's "seconds" is heard, but it does not lead to Black Bear's refrain. The 
refrain finally enters at 1:44, without begin introduced by the "seconds." Its entrance anticipates the drop of "chorus":

\author{
Ameen and Ameen \\ Ameen and Ameen \\ Yasiin and Yassin and the R.E.D. \\ Ameen and Ameen \\ Original Nation \\ Ameen and Ameen \\ Strait Jacket Come Clean \\ Yasiin and Yassin and the R.E.D. \\ Original Nation \\ True and Living you know we're True and Living.
}

The "seconds" is brought in to coincide with the final two phrases of the chorus.

The video reinforces the oppressive presence of the Alie Nation and nation-state boundaries. This depiction is timely, given Bey's detention in South Africa for trying to use a "global passport." The lyrics and video for "The Virus" further dramatize Trudell's words by situating us on "Turtle Island in 2047" as the Halluci and Alie Nations are now real, with members of the Halluci Nation declaring, "We are not a conquered people," despite the state violence of the Alie Nation. Most of the video takes place in a dark cavern with members of the Halluci Nation surrounding the nation's seal, which glows on the ground in the centre. Individuals dance to ATCR's beat, as the visuals shift abruptly back and forth between the cavern and clips of protest and violence. ${ }^{6}$ The Halluci Nation is built through transnational and inter-tribal allegiances, based on a common goal of resistance as well as resurgence: to re-vision a decolonized existence.

Eve Tuck and K. Wayne Yang insist, "When metaphor invades decolonization, it kills the very possibility of decolonization, it recenters whiteness, it resettles theory, it extends innocence to the setter, it entertains a settler future" $(2012,3)$. Decolonization requires "the repatriation of land simultaneous to the recognition of how land and relations to land have always been differently understood and enacted" (7). This repatriation is not only about accepting the truth of violent settler colonialism and Indigenous genocide in North America or even of reconciliation, the desire for which, they argue, "is a desire to not have to deal with this (Indian) problem anymore" (9). Decolonization comes only when the settler-native-slave triad is broken, not merely re-apportioned. Decolonization is unsettling.

Their article explains how the systems that reinforce settler colonialism are strong, and social justice efforts are often more focused on resettlement and reoccupation, which only reinforce settler colonialism rather than dismantle it. But Indigenous artists, scholars, and leaders speak of decolonization

6 Watch the video at https://www.youtube.com/watch? $\mathrm{v}=4$ 5VAKdHMek. The video, directed by Tunkasila, includes Monique Mojica (Mama Bear), Devery Jacobs, Rupi Kaur, Narcy, and Dre Ngozi (among others) in the roles of Guardian, Elder, or Refugee. 
happening now, even before the repatriation of land. And the role of Indigenous artists is central.

ATCR's music is a powerful sonification of embodied global allegiances, decolonization, and Indigenous activism. This music sonifies agency, language, identity, and the everyday practices of Indigenous artists, for, as Jeff Corntassel explains, "It is in these everyday actions where the scope of the struggle for decolonization is reclaimed and re-envisioned by Indigenous peoples. Decolonizing praxis comes from moving beyond political awareness and/or symbolic gestures to everyday practices of resurgence" $(2012,89)$. ATCR sees these everyday practices of resurgence on a global scale. With Halluci Nation (2016), ATCR seeks to foster far-reaching allegiances across culture, ethnicity, and place to, according to DJ NDN, "[understand] oppression and how to collectively dismantle oppression" (Monture 2016). John Trudell's vision and the musical world of the Halluci Nation not only allow us to imagine the dream but also to hear it become a reality through the collaborative work and revisioning of these diverse allies.

\section{REFERENCES}

Andersen, Chris. 2013. "Urban Aboriginality as a Distinctive Identity, in Twelve Parts." In Peters and Andersen, Indigenous in the City, 46-68.

Barnes,Tom. 2016. "A TribeCalled Red Aim toUnite Artists, ActivistsagainstColonialism on 'Halluci Nation." Mic, 12 July. https://mic.com/articles/148474/ a-tribe-called-red-aim-to-unite-artists-activists-against-colonialism -on-halluci-nation\#.kPootdOfc.

Browner, Tara, ed. 2009. Music of the First Nations: Tradition and Innovation in Native North America. Urbana, IL: University of Chicago Press.

Corntassel, Jeff. 2012. "Re-envisioning Resurgence: Indigenous Pathways to Decolonization and Sustainable Self-Determination." Decolonization: Indigeneity, Education \& Society 1 (1): 86-101.

Francis, Daniel. 1992. The Imaginary Indian: The Image of the Indian in Canadian Culture. Vancouver: Arsenal Pulp.

Johnson, Jay T. 2013. "Dancing into Place: The Role of the Powwow within Urban Indigenous Communities." In Indigenous in the City: Contemporary Identities and Cultural Innovations, eds. Evelyn Peters and Chris Andersen, 216-30. Vancouver: UBC Press.

Josephy, Alvin M. 1999. Red Power: The American Indians' Fight for Freedom. Lincoln, NE: University of Nebraska Press.

King, Thomas. 2012. The Inconvenient Indian: A Curious Account of Native People in North America. Minneapolis: University of Minnesota Press.

Kino-nda-niimi Collective, ed. 2014. The Winter We Danced: Voices from the Past, the Future, and the Idle No More Movement. Winnipeg: ARP, 2014.

Leal, Melissa. 2012. "Chempa, Showinpa, Mefpa, Asumpa, Achepa (to Paint, to Scratch, to Dance, to Flow, to Unite): The Native American Experience in the Hip Hop World." PhD diss., University of California, Davis.

Lee, Erica Violet, and Hayden King. 2017. "The Wigwam Conspiracy: Why Are Canada 150’s Indigenous People Stuck in Time?” CBC: Opinion, 30 March. 
http://www.cbc.ca/2017/the-wigwam-conspiracy-why-are-canada-150-s -indigenous-people-stuck-in-time-1.4034974.

Monture, Lindsay. 2016. "A Tribe Called Red's DJ NDN Talks New Album, Collaboration, and Solidarity." Revolutions Per Minute (RPM), 8 September. http://rpm.fm/interview/ tribe-called-reds-dj-ndn-talks-new-album-collaboration-solidarity/.

Perea, John-Carlos. 2013. Intertribal Native American Music in the United States: Experiencing Music, Expressing Culture. New York: Oxford University Press.

Peters, Evelyn, and Chris Andersen, eds. 2013. Indigenous in the City: Contemporary Identities and Cultural Innovations. Vancouver: UBC Press.

Recollet, Karyn. 2015. "For Sisters." In Me Artsy, ed. Drew Hayden Taylor, 91104. Madiera Park: Douglas \& McIntyre.

Scales, Christopher. 2012. Recording Culture: Powwow Music and the Aboriginal Recording Industry on the Northern Plains. Durham, NC: Duke University Press.

Simpson, Leanne. 2011. Dancing on Our Turtle's Back: Stories of Nishnaabeg Re-Creation, Resurgence, and a New Emergence. Winnipeg: Arbeiter Ring Publishing.

Tuck, Eve, and K. Wayne Tang. 2012. "Decolonization Is Not a Metaphor." Decolonization: Indigeneity, Education \& Society 1 (1): 1-40.

Woloshyn, Alexa. 2015. "Hearing Urban Indigeneity in Canada: Self-Determination, Community Formation, and Kinaesthetic Listening." American Indian Culture and Research Journal 39 (2): 1-23.

\begin{abstract}
"We are the tribe that they cannot see. We live on an industrial reservation. We are the Halluci Nation." These words from Indigenous activist and poet John Trudell (19462015) inspired the latest album by Ottawa-based Indigenous DJ collective A Tribe Called Red (ATCR) and frame its pan-Indigenous, transcultural message. Inter-tribal relationships are both common and important to Indigenous communities, especially in urban centres. Powwows are also events that emphasize intertribal and intercultural relationships, even as they hosted by a specific nation. With Halluci Nation, ATCR seeks to foster far-reaching allegiances across culture, ethnicity, and place to "[understand] oppression and how to collectively dismantle oppression" (DJ NDN of ATCR).

This article argues that ATCR's Halluci Nation sonifies a process of decolonization that establishes an embodied network of global allies. I trace the development of ATCR's music from its original focus on the Ottawa Indigenous community and its non-Indigenous allies to a call for nation-to-nation relationships (see Juno Awardwinning album Nation II Nation, 2013), and then now to a concept album that seeks to manifest a real "Halluci Nation" with members from around the world. Analysis of ATCR's music, audience, and Halluci Nation album is contextualized by studies of community formation and identity politics in intertribal initiatives), such as powwows and friendship centres, and pan-Indigenous activism, such as Idle No More.
\end{abstract}




\section{RÉSUMÉ}

«Nous sommes la tribu invisible. Nous vivons sur une réserve industrielle. Nous sommes la nation Halluci». Ces paroles de l'activiste des droits autochtones et poète John Trudell (1946-2015) a inspiré le plus récent album du collectif autochtone de disc-jockeys A Tribe Called Red (ATCR), de même que sa cause pan-autochtone et transculturelle. Les relations intertribales sont à la fois fréquentes et importantes pour les communautés autochtones, particulièrement dans les centres urbains. Leurs relations intertribales sont d'ailleurs soulignées par des événements tels que des powwows, même lorsqu'ils sont organisés par une nation en particulier. Avec Halluci Nation, ATCR cherche à rassembler des allégeances communes à travers une variété de cultures, d'identités ethniques et de lieux afin de comprendre l'oppression et comment elle peut être démantelée collectivement (DJ NDN de ATCR). Cet article avance que Halluci Nation de ATCR traduit par le son une démarche de décolonisation donnant lieu à un réseau global d'alliances. Nous retraçons le développement de la musique de ATCR, à partir de son intérêt de départ pour la communauté autochtone de la région d'Ottawa et ses alliés non-autochtones, vers un appel à des relations nation-à-nation (voir le Prix Juno - album gagnant Nation II Nation, 2013), pour aboutir au récent album-concept qui cherche à rassembler ses membres à l'échelle mondiale en une réelle Nation Halluci. Les analyses de la musique de ATCR, de son public, et de l'album Halluci Nation sont effectuée dans le cadre d'une étude de la formation de communauté et de politiques identitaires dans l'action intertribale, telle que l'organisation de powwows, de centre d'amitié, et l'activisme pan-autochtone comme Idle No More.

\section{BIOGRAPHY}

Alexa Woloshyn is an assistant professor of musicology at Carnegie Mellon University. Her research focuses on how electronic, physiological, and socio-cultural technologies mediate the creation and consumption of musical practices in both art and popular musics. Current research projects examine performance practice in live electronic music and Indigenous musicians' use of mediating technologies to construct and interrogate notions of "modern" Indigeneity, including Tanya Tagaq and A Tribe Called Red. Her work has been published in Circuits: musiques contemporains, eContact!, the American Indian Culture and Research Journal, TEMPO, and the Journal of Popular Music Studies. 